\title{
Using transmissivity, specific capacity and borehole yielddata to assess the productivity of Scottish aquifers
}

\author{
M.T. Graham, D.F. Ball, B.É. Ó Dochartaigh* \& A.M. MacDonald \\ British Geological Survey, Murchison House, West Mains Road, Edinburgh EH9 3LA, UK \\ *Corresponding author (e-mail: beod@bgs.ac.uk)
}

\begin{abstract}
Aquifer properties data from more than 3000 groundwater sources across Scotland have been collated to form the Scottish Aquifer Properties Database, coordinated by the Scotland and Northern Ireland Forum for Environmental Research. The aim of the project was to better understand Scotland's aquifers, through the collation of a comprehensive set of quantitative data. Analysis of 157 transmissivity values, 307 specific capacity values and 1638 borehole yield values shows that Quaternary and Permo-Triassic age aquifers are the most productive, followed by those of Devonian and Carboniferous age. There is a strong correlation between specific capacity and transmissivity $(r 2=0.8)$, and the former may be used as a reliable indicator of aquifer productivity where no transmissivity data are available. The correlation between transmissivity and borehole yield data is significant ( $r 2=0.57)$, although the quality of the yield data is lower overall than that of the specific capacity or transmissivity data. These data support recent categorization of bedrock aquifer productivity in Scotland, which until now has been validated only with limited quantitative datasets.
\end{abstract}

Groundwater has played an increasingly important role in both private and public water supplies in Scotland in recent years. The Scottish Environmental Protection Agency (SEPA) estimates that there are around 30000 private groundwater supplies in Scotland (SEPA 2003), and the total yield from borehole abstractions by Scottish Water more than doubled between 1990 and 2005, to more than $100 \mathrm{Ml} \mathrm{day}^{-1}$ (Scottish Water 2005). Groundwater also contributes a major component of baseflow to Scotland's rivers, supporting world-class salmon and trout fishing as well as a wide variety of other wildlife. Until recently, however, there has been relatively limited regulation of groundwater usage in Scotland and a lack of a coherent strategy for groundwater management at a national level.

The Water Framework Directive (2000/60/EC) (European Commission 2000) set out new objectives for groundwater management across Europe. In Scotland, it has been implemented through the Water Environment and Water Services Act 2003, which includes a requirement for regulatory authorities to gain a better understanding of available groundwater resources and of how they interact with surface water bodies and ecosystems (Clews et al. 2005).

Against this background, a 2 year collaborative project between the British Geological Survey (BGS) and SEPA was set up, coordinated by the Scotland and Northern Ireland Forum for Environmental Research. The aim of the study was to collect, collate and present a wide range of information on groundwater sources across Scotland, with a particular emphasis on quantitative aquifer properties data, such as transmissivity and specific capacity. A major component of the study was the creation of the Scottish Aquifer Properties Database (SAPD). This paper presents an analysis of all the transmissivity, specific capacity and borehole yield values held by the database, followed by a comparison of these datasets with the map of bedrock aquifer productivity for Scotland (MacDonald et al. 2004, 2005). 


\section{Overview of aquifer properties studies in Scotland}

Despite the widespread use of groundwater, relatively few studies have been conducted on the physical properties of Scotland's aquifers and previous work at a national scale has taken a mainly qualitative approach. Work by Robins (1990) and MacDonald et al. (2005) gives a useful overview of the nature of Scotland's aquifers and of the requirements for further data to characterize them. A hydrogeological map of Scotland (BGS 1988) divides Scotland's aquifers into broad groups, based on qualitative descriptions of their flow characteristics, and includes the locations of known groundwater sources. This was updated to produce an aquifer productivity map of Scotland (MacDonald et al. 2005), which is currently used by SEPA in the implementation of groundwater strategy at a national level. The categorization relies mainly on expert opinion, and up to now validation with quantitative datasets has been limited (MacDonald et al. 2005).

Studies incorporating significant quantitative aquifer properties data have focused on regionally important aquifers, such as those in Fife and Dumfries (Robins \& Buckley 1988; Ó Dochartaigh et al. 1999; Ó Dochartaigh 2004; Robins \& Ball 2006). Until now, comprehensive datasets of the type used in these studies have not been collated to allow quantitative characterization of all Scotland's aquifers.

Detailed statistical summaries of aquifer properties at a national scale are available in England and Wales. Allen et al. (1997) used pumping test data from more than 2500 sites and core analysis data from more than 700 sites to describe the physical properties of major aquifers, and in a similar study of minor aquifers, Jones et al. (2000) used pumping test data from more than 1700 sites and core analyses from more than 200 sites.

In predominantly hard rock areas where few transmissivity data are available, a number of studies have examined the use of borehole yield and specific capacity data as measures of aquifer productivity (Wright 2000; Banks et al. 2005; Betson \& Robins 2007). In particular, Wright (2000) has used comparisons of borehole yield and specific capacity data to infer the productivity of aquifers in Ireland.

\section{The hydrogeology of Scotland}

A broad qualitative understanding currently exists of the hydrogeology of Scotland. A summary of the main stratigraphic units in Scotland and their hydrogeological properties is given in Table 1, and their spatial extent is shown in Figure 1. 
Table 1. Summary of the main stratigraphic units in Scotland and their hydrogeological properties

\begin{tabular}{|c|c|c|c|}
\hline Aquifer & Dominant lithology & Productivity $^{1}$ & Dominant flow type \\
\hline Quaternary & $\begin{array}{l}\text { Alluvial sand and gravel; } \\
\text { glaciofluvial sand and } \\
\text { gravel; raised marine } \\
\text { deposits; sandy and } \\
\text { gravelly glacial deposits }\end{array}$ & Very High to Low & Intergranular \\
\hline $\begin{array}{l}\text { Jurassic, Cretaceous \& } \\
\text { Tertiary }\end{array}$ & Sandstone & Moderate & $\begin{array}{l}\text { Mixed intergranular - } \\
\text { fracture }\end{array}$ \\
\hline Permo-Triassic & Sandstone and breccia & $\begin{array}{l}\text { Very High (Permian } \\
\text { sandstone in } \\
\text { Dumfriesshire only) to } \\
\text { Moderate }\end{array}$ & $\begin{array}{l}\text { Dominantly } \\
\text { intergranular to mixed } \\
\text { intergranular - fracture }\end{array}$ \\
\hline Carboniferous & $\begin{array}{l}\text { Mixed sedimentary } \\
\text { sequences of sandstone, } \\
\text { siltstone, mudstone, coal } \\
\text { and limestone }\end{array}$ & $\begin{array}{l}\text { High (Passage } \\
\text { Formation only) to } \\
\text { Moderate }\end{array}$ & $\begin{array}{l}\text { Dominantly } \\
\text { intergranular (Passage } \\
\text { Formation only) to } \\
\text { mixed intergranular - } \\
\text { fracture }\end{array}$ \\
\hline Devonian & $\begin{array}{l}\text { Dominantly sandstone } \\
\text { and breccia; minor } \\
\text { flagstone, siltstone and } \\
\text { limestone }\end{array}$ & $\begin{array}{l}\text { Very High (Upper } \\
\text { Devonian in Fife } \\
\text { only) to Low }\end{array}$ & $\begin{array}{l}\text { Dominantly } \\
\text { intergranular (Upper } \\
\text { Devonian in Fife only); } \\
\text { mixed intergranular - } \\
\text { fracture; fracture } \\
\text { (flagstone only) }\end{array}$ \\
\hline Ordovician/Silurian & Dominantly greywacke & Low & Fracture \\
\hline $\begin{array}{l}\text { Precambrian/Cambro- } \\
\text { Ordovician }\end{array}$ & $\begin{array}{l}\text { Sandstone (Torridonian), } \\
\text { limestone and dolomite } \\
\text { (Cambrian), } \\
\text { metamorphic rocks } \\
\text { (dominantly schists and } \\
\text { gneisses) }\end{array}$ & $\begin{array}{l}\text { Moderate (Cambrian } \\
\text { limestone and } \\
\text { dolomite only) to } \\
\text { Very Low }\end{array}$ & Fracture \\
\hline Igneous (all ages) & $\begin{array}{l}\text { Lavas, volcaniclastic } \\
\text { sediments, intrusions }\end{array}$ & $\begin{array}{l}\text { Moderate } \\
\text { (Carboniferous lavas } \\
\text { in East Lothian only) } \\
\text { to Very Low }\end{array}$ & Fracture \\
\hline
\end{tabular}

\footnotetext{
${ }^{1}$ The productivity rating refers to the estimated typical long-term yield from a single, properly sited and constructed borehole. Very High: > 20 l/s; High: 10 - 20 l/s; Moderate: 1-10 l/s; Low 0.1-1 l/s; Very Low <0.1 l/s
} 


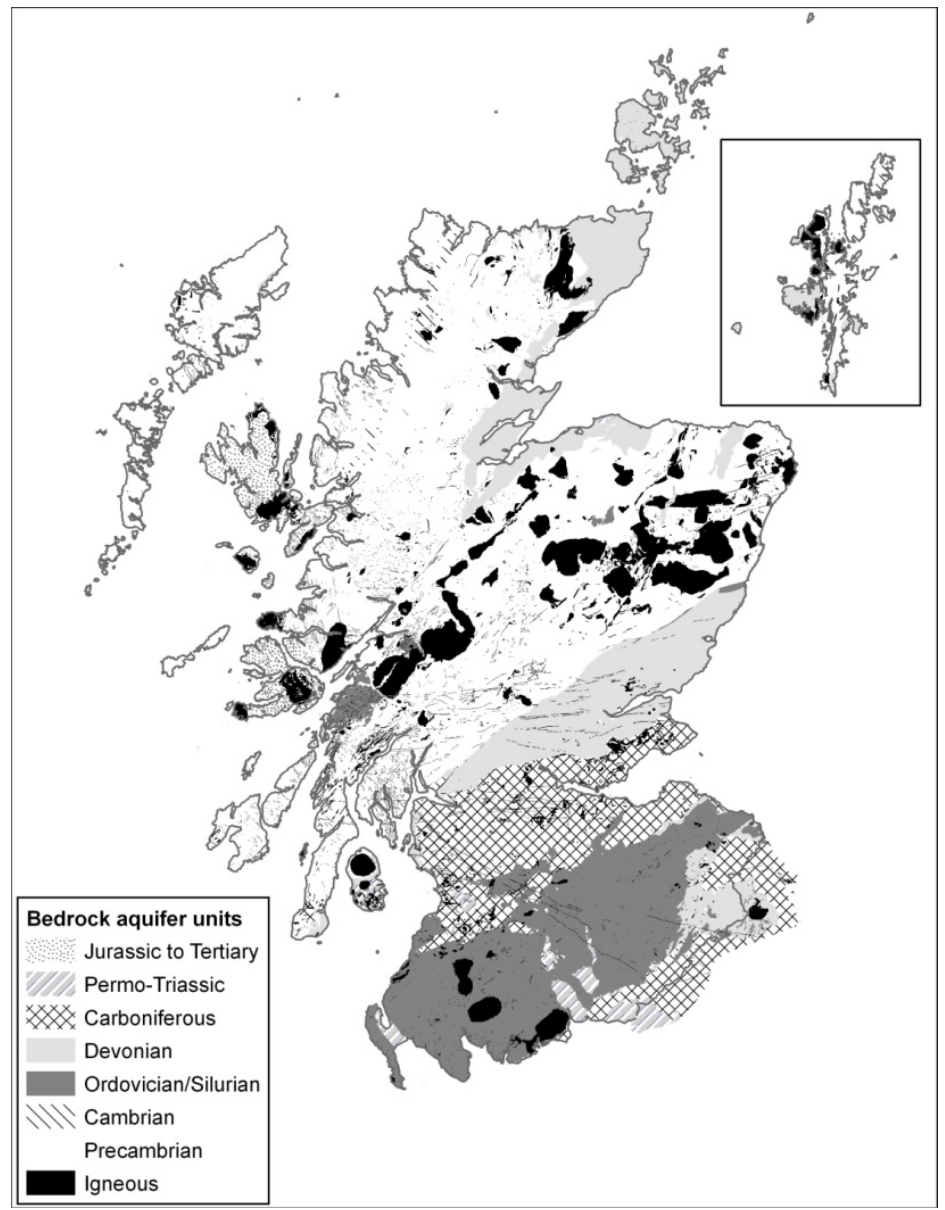

Figure 1: Map of the main bedrock aquifer units in Scotland, classified by stratigraphy.

\section{The Scottish Aquifer Properties Database}

The Scottish Aquifer Properties Database (SAPD) was produced to address the current lack of a comprehensive national dataset of aquifer properties and to facilitate strategic planning of groundwater resources. The SAPD provides data on nearly 3500 groundwater sources across Scotland, comprising boreholes, springs, shafts and wells. It brings together data from a range of digital sources held by the BGS, as well as nearly 60 unpublished technical reports. In addition, further aquifer properties data were collected as part of the project.

The SAPD holds data on a wide range of hydrogeological parameters, including transmissivity, specific capacity, borehole yield, storativity, porosity and permeability. Although transmissivity is commonly recognized as being the most suitable parameter in determining aquifer productivity, there are relatively few sites across Scotland for which such data have been collected. Borehole yield data represent by far the most commonly recorded parameter, followed by specific capacity (Table 2).

This paper focuses on the suitability of transmissivity, specific capacity and borehole yield data as a measure of aquifer productivity in Scotland. Statistical summaries are presented for each parameter. The data are also used to validate the existing aquifer productivity map of Scotland (MacDonald et al. 2004). 
Table 2. Data held by the Scottish Aquifer Properties Database for each of six hydrogeological parameters

\begin{tabular}{lc}
\hline Parameter & Number of sites with data \\
\hline Transmissivity & 157 \\
Storativity & 58 \\
Specific capacity & 307 \\
Yield & 1638 \\
Porosity & 104 \\
Permeability & 103 \\
\hline
\end{tabular}

\section{Data quality and bias}

The data in the SAPD have been divided into three categories, based on their quality. Highquality data refer to transmissivity, specific capacity and borehole yield data taken from a constant rate pumping test of at least 24 hours duration. In the case of yield data, the maximum drawdown in the test must be less than $20 \%$ of the initial depth of water in the borehole. This condition has been used to limit the number of boreholes that may be unsustainable in the long term as a result of excessive drawdown values. Normal operational borehole yield data, spanning a period of at least 2 years, or spring flow data covering a period of at least 1 year, are also classed as high quality.

Pumping test data that fail to meet the above criteria are classed as being of intermediate quality. Normal operational borehole yield data of less than 2 years duration or spring flow data of unknown quality covering a period of at least 1 year also fall into this category.

Data that fail to meet the criteria for the above categories are classed as being of poor quality. This category comprises non-pumping test data from boreholes, which are not representative of the normal operational yield, as well as any borehole data from unknown sources and spring flow data spanning a period of less than 1 year.

The most plentiful data (borehole yield data of poor quality) are also the least informative in determining aquifer productivity (Table 3). Although it would clearly be preferable to have abundant transmissivity data of a good quality for each type of aquifer, the SAPD holds no data of this type for Ordovician, Silurian and igneous aquifers.

Borehole yield data have been used in the past to characterize the productivity of aquifers (Banks et al. 2005), although there are a number of reasons why this approach can lead to unreliable estimates of aquifer productivity:

(1) yield values that do not meet the minimum requirements of a site are less likely to be recorded (the same argument can be applied to specific capacity and transmissivity values in poorly productive boreholes);

(2) recorded yield values are often based on short pumping tests and may not be sustainable in the long term; 
(3) the yield value recorded for a site may be lower than the maximum sustainable yield of the borehole. This may be due to low demand or low pump capacity.

Table 3. Available transmissivity, specific capacity and borehole yield data, classified by quality category

\begin{tabular}{lccc}
\hline \multicolumn{1}{c}{ Quality Category } & No. of sites with data & \\
& Transmissivity & Specific capacity & Borehole yield \\
\hline High & 109 & 122 & 108 \\
Intermediate & 41 & 168 & 577 \\
Low & 7 & 17 & 953 \\
\hline
\end{tabular}

Table 4. Number of sites with borehole yield, specific capacity and transmissivity data, classified by stratigraphy

\begin{tabular}{lccc}
\hline & & No. of sites with data & \\
& Transmissivity & Specific capacity & Borehole yield \\
\hline Quaternary & 40 & 62 & 199 \\
Jurassic & 1 & 4 & 4 \\
Permo-Triassic & 49 & 54 & 105 \\
Carboniferous & 5 & 46 & 550 \\
Devonian & 46 & 88 & 320 \\
Ordovician/Silurian & - & 5 & 94 \\
Precambrian/Cambro- & & 18 & 47 \\
Ordovician & 11 & 17 & 88 \\
Igneous & - & 13 & 231 \\
Unclassified & 5 & 300 & 1638 \\
Total & 157 & & \\
\hline
\end{tabular}

Although specific capacity data are likely to be affected to a lesser degree by the above phenomena, specific capacity values are still dependent on the chosen borehole yield to some extent and may also lead to inaccurate estimates of aquifer productivity. Transmissivity values are less dependent on borehole yield, and therefore represent a more reliable gauge of aquifer productivity, where they are available.

There is a clear bias in the available data towards aquifers in the more populated parts of central Scotland (in Carboniferous and Devonian aquifers) where demand is high, and towards aquifers that are known to be particularly productive (Devonian, Permo-Triassic and Quaternary) (Table 4 and Figure 2). Precambrian and Cambro-Ordovician rocks represent the 
largest group of bedrock aquifers in terms of surface area and cover the majority of Scotland north of the Midland Valley, but few data are available for this category.

A similar bias is likely to occur on a local scale, whereby formations that are already known to be highly permeable are more likely to be exploited for groundwater abstractions, as are areas with an increased likelihood of intense fracturing of the rock, such as valley floors, or the vicinity of fault zones.

In addition to issues of spatial bias, it is important to note that many of the recorded transmissivity values were derived using only data from the abstraction borehole during constant rate tests, and there may be slight underestimates of transmissivity as a result of a failure to take well losses into account. Conversely, overestimates of transmissivity within an aquifer may be caused by a greater number of pumping tests being carried out on boreholes with high yields.

\section{General statistics}

The distributions of transmissivity, specific capacity and borehole yield data, classified by stratigraphic period, are shown in Figure 3. A separate category is included for igneous aquifers.

The Quaternary, Carboniferous, Permo-Triassic and Devonian aquifers are particularly productive, with median transmissivity values of $350 \mathrm{~m}^{2}$ day $^{-1}, 150 \mathrm{~m}^{2}$ day $^{-1}, 134 \mathrm{~m}^{2}$ day $^{-1}$ and $61 \mathrm{~m}^{2}$ day $^{-1}$, respectively. Few data are available for other aquifer groups. The small number of data for the Carboniferous is heavily influenced by pumping tests carried out in the highly productive Kinnesswood Sandstone Formation of Fife.

The specific capacity data show a similar pattern to the transmissivity data, with Quaternary and Permo-Triassic aquifers being the most productive (with median specific capacity values of $283 \mathrm{~m}^{3}$ day $^{-1} \mathrm{~m}^{-1}$ and $117 \mathrm{~m}^{3}$ day $^{-1} \mathrm{~m}^{-1}$, respectively), followed by aquifers of Devonian and Carboniferous age (with median specific capacity values of $50 \mathrm{~m}^{3}$ day $^{-1} \mathrm{~m}^{-1}$ and $48 \mathrm{~m}^{3}$ day $^{-1}$ $\mathrm{m}^{-1}$, respectively). All other groups have median specific capacity values of less than $10 \mathrm{~m}^{3}$ day $^{-1} \mathrm{~m}^{-1}$.

There are most data for borehole yield, with more than 1600 values available. Figure 3 shows that the highest values generally occur in Carboniferous aquifers affected by mining activity, with a median yield of $1987 \mathrm{~m}^{3} \mathrm{day}^{-1}$, nearly four times the magnitude of the next most productive group of aquifers. Until the late 20th century, coal mining was prevalent across much of central Scotland. In addition to increasing the overall permeability of many Carboniferous aquifers, mine shafts often represent complex groundwater sources, drawing water from several linked adits and other shafts (Woods et al. 1999). In the absence of mining activity, Permo-Triassic aquifers clearly have the highest borehole yields, with a median value of $527 \mathrm{~m}^{3}$ day $^{-1}$, followed by the Quaternary, the Devonian and the Carboniferous, with median values of $190 \mathrm{~m}^{3}$ day $^{-1}, 168 \mathrm{~m}^{3}$ day $^{-1}$ and $147 \mathrm{~m}^{3}$ day $^{-1}$, respectively. All other groups have median borehole yields of less than $100 \mathrm{~m} 3$ day $^{-1}$. 


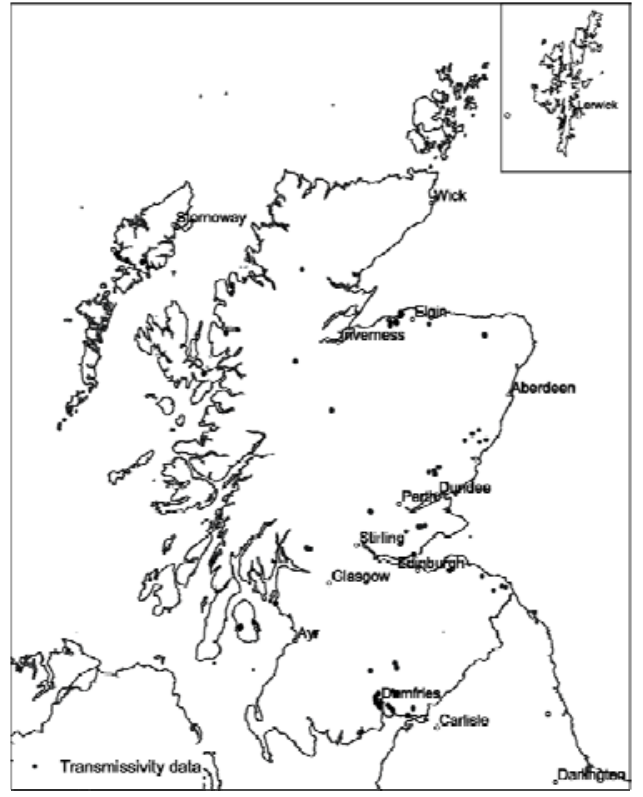

(a)

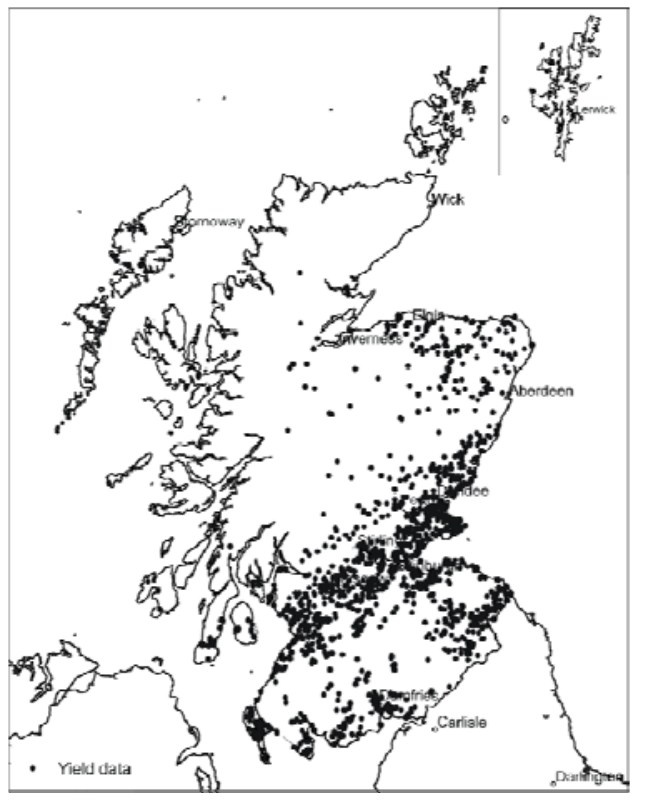

(c)

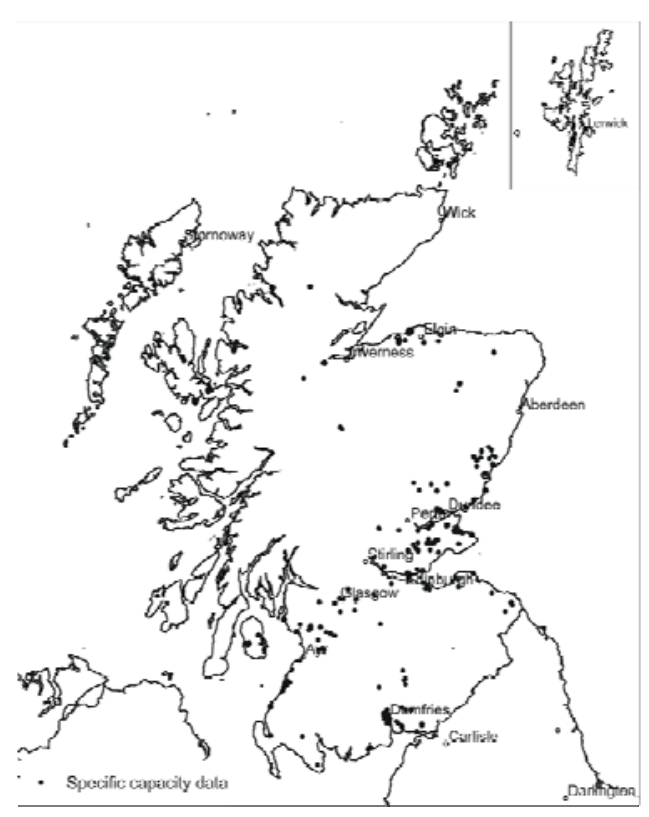

(b)

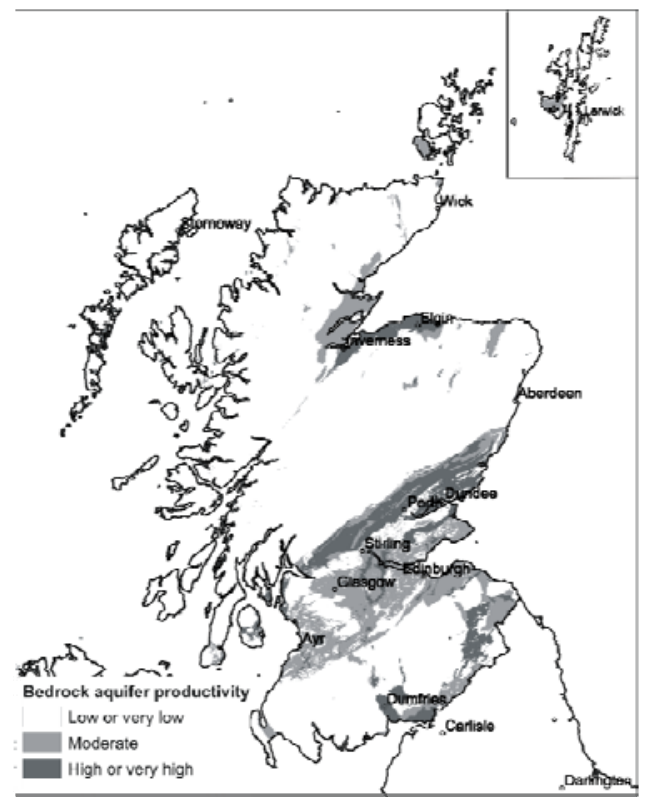

(d)

Figure 2. Distribution of available (a) transmissivity, (b) specific capacity and (c) borehole yield data, with (d) a map of aquifer productivity in Scotland (after MacDonald et al., 2004). 


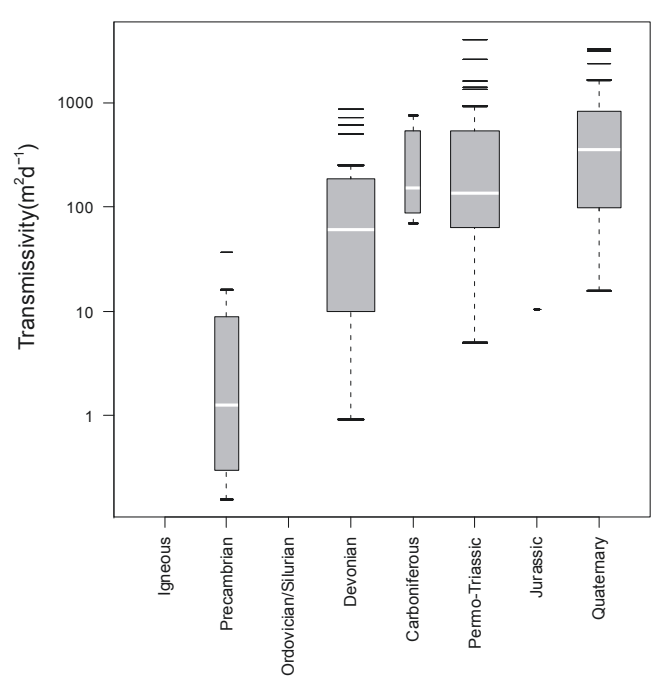

(a)

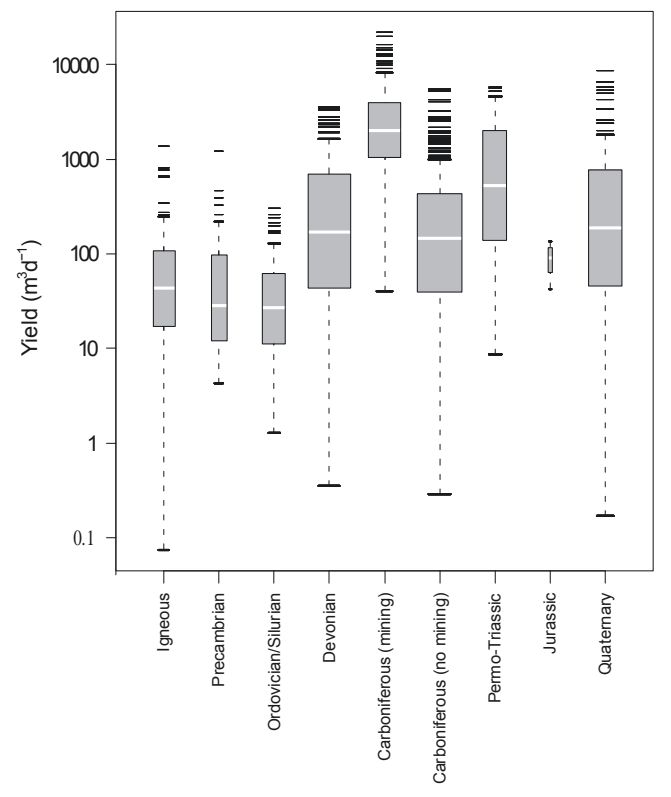

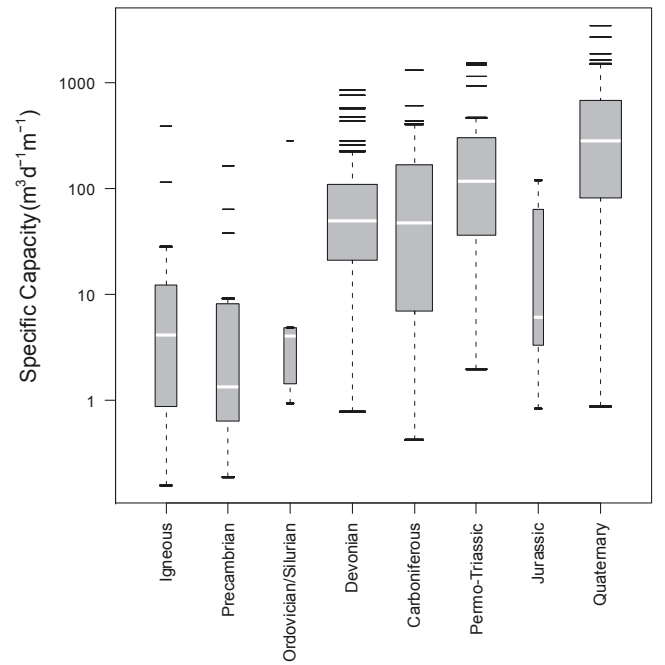

(b)

(c)

Figure 3. Boxplots of (a) transmissivity, (b) specific capacity and (c) borehole yield data, categorised by stratigraphic group. The width of each box is proportional to the square root of the number of data points. 


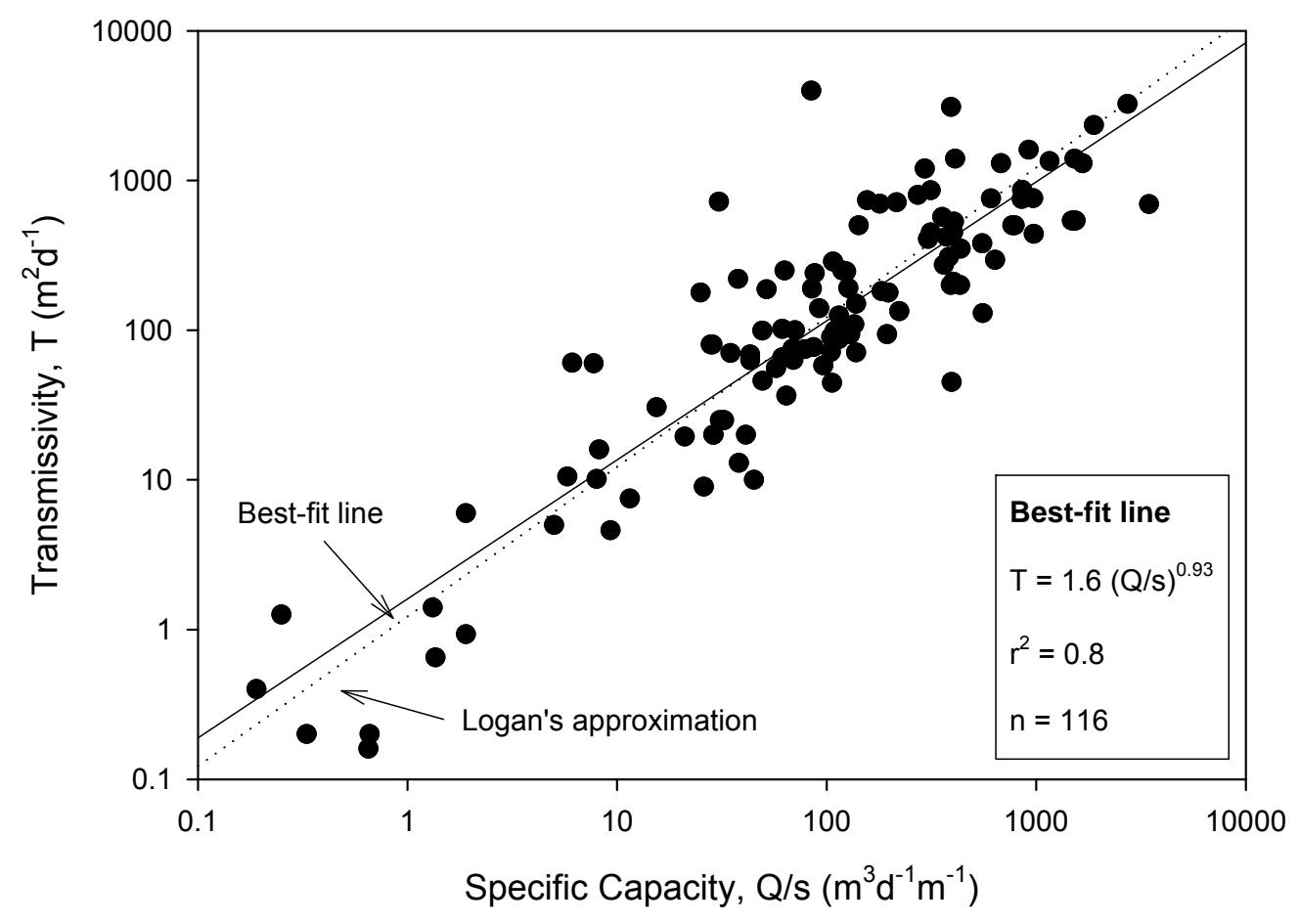

Figure 4. The relationship between transmissivity data (including values derived from pumped boreholes) and specific capacity (not steady state).

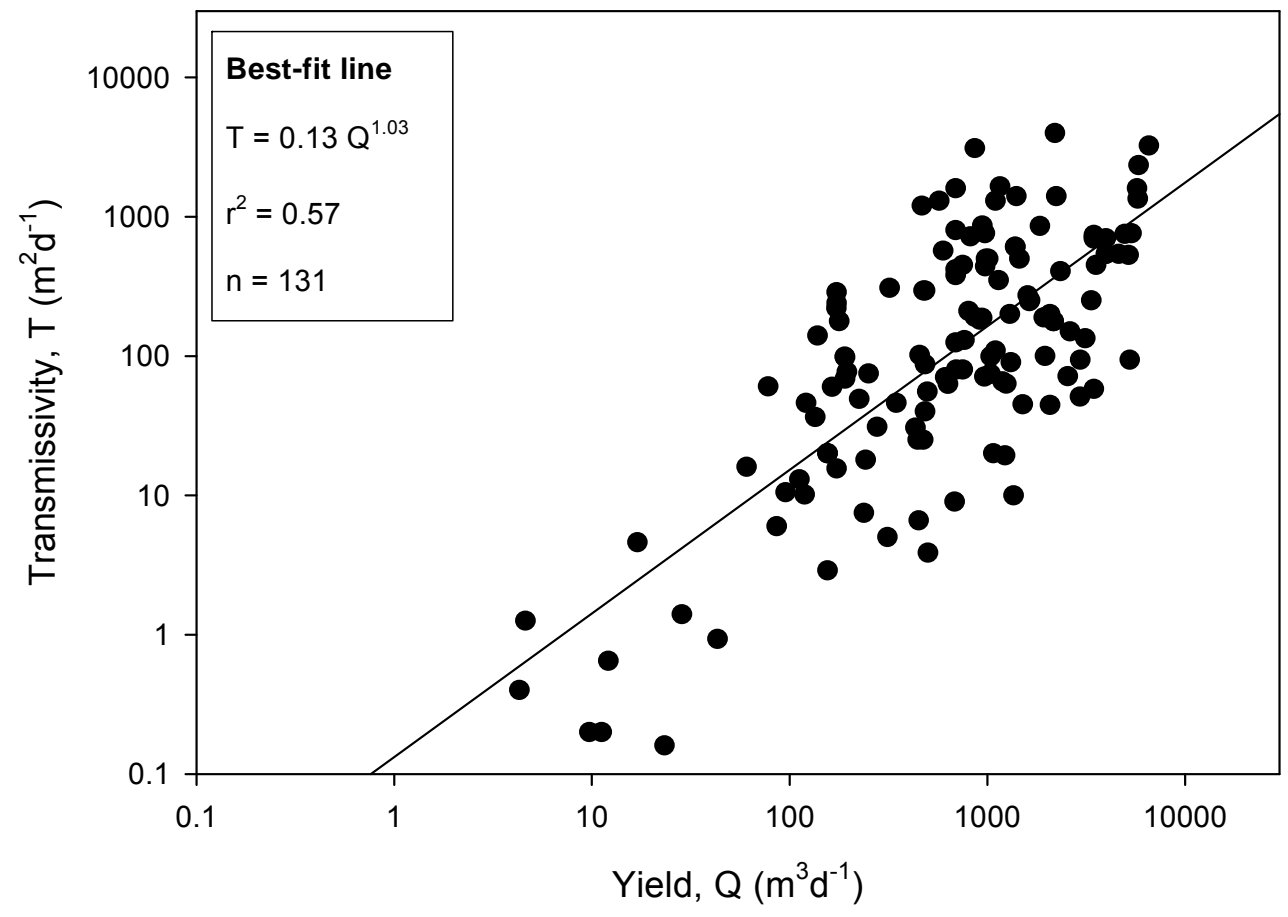

Figure 5. The relationship between specific capacity data (not steady state) and borehole yield. 
Logan's approximation represents a generalized, but simplified, relationship between transmissivity and specific capacity values. Its limitations, described in more detail by Misstear (2001), mean that it has not been used to derive any parameter values for the SAPD, although the data show that it may act as a reasonable approximation for a range of different aquifer types. The data suggest that specific capacity may be an acceptable measure of aquifer productivity in the absence of transmissivity data. However, the predominance of transmissivity values from single-borehole tests that do not account for well losses may partially account for the close correlation between these parameters.

As only borehole yield data are available for many sites in the SAPD, it is important to establish the relative level of bias within this parameter. This can be achieved by relating borehole yield data to the corresponding values of specific capacity and transmissivity. There are 302 sites in the SAPD for which both borehole yield data and specific capacity data are available. The two parameters are reasonably closely related, with an $r^{2}$ value of 0.62 for the best-fit line (Figure 5), although this suggests a significantly weaker correlation than was found between specific capacity and transmissivity. Borehole yield may, therefore, be a fair indicator of aquifer productivity in the absence of specific capacity or transmissivity values.

Further evidence of this is provided by the relationship between borehole yield data and transmissivity data, based on values from 131 sites (Figure 6). The quality of fit, shown by an $r^{2}$ value of 0.57 for the best-fit line, is still significant and demonstrates that borehole yield can be used to scale up the other data across Scotland. 


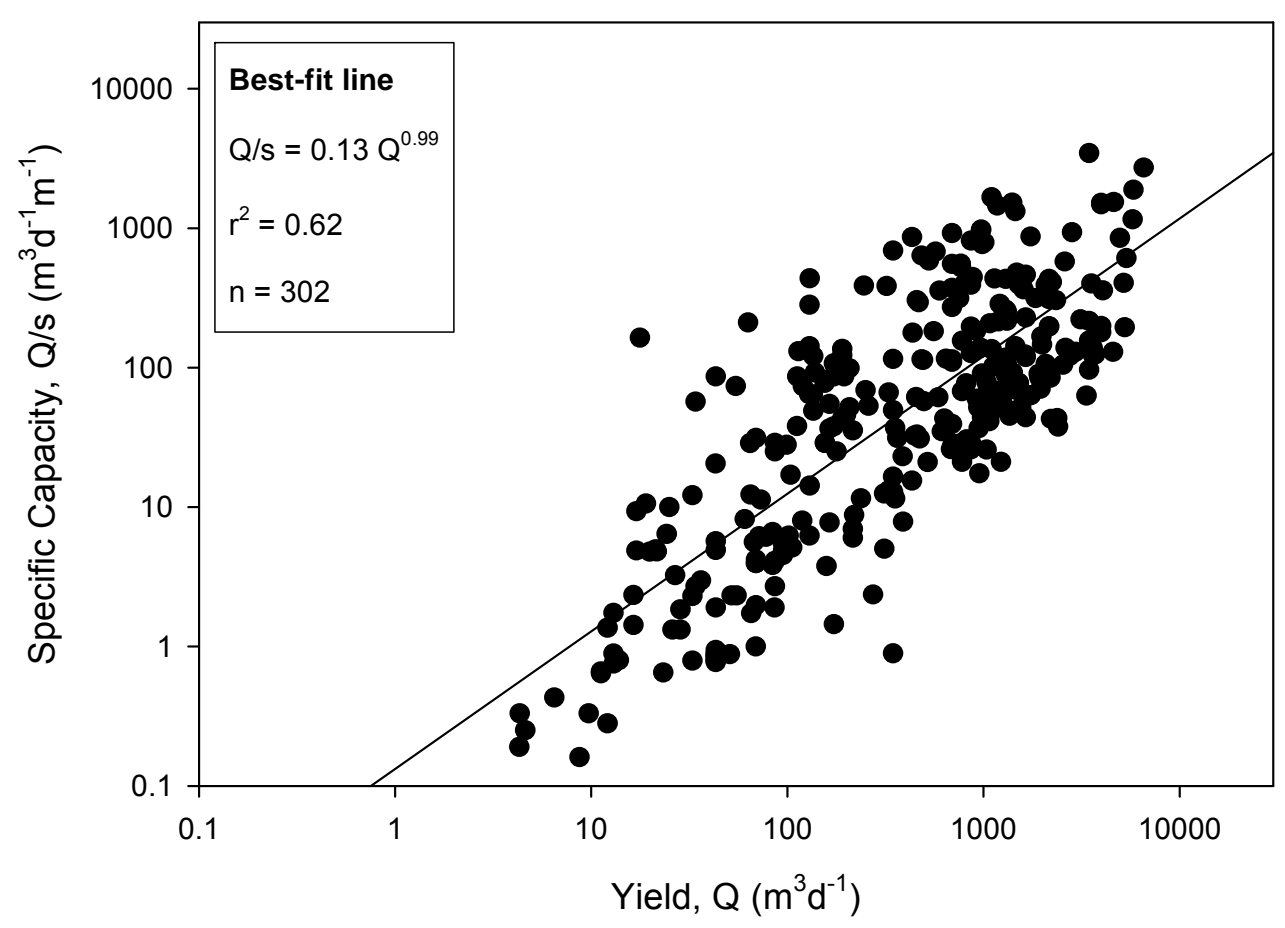

Figure 6. The relationship between transmissivity data (including values derived from pumped boreholes) and borehole yield.

\section{Comparisons with the existing map of bedrock aquifer productivity}

In general, there is good agreement between the available data for all three parameters and the categories assigned to the existing bedrock aquifer productivity map of Scotland (MacDonald et al. 2005; Figure 7).

Aquifers classed as being of very low productivity have median transmissivity and specific capacity values that are around one order of magnitude lower than the median values of low productivity aquifers, and two orders of magnitude lower than those of moderate productivity aquifers. This contrasts with the borehole yield data, in which the median values of very low, low and moderate productivity aquifers are within one order of magnitude. This may be caused by bias in the yield data, the sources of which are discussed above.

The only notable discrepancy occurs in the comparison between the available transmissivity data and the categories assigned to the existing aquifer productivity map. Aquifers classed as being highly productive appear to show a lower median transmissivity than those classed as being moderately productive. Further data collection may be required in this regard, to determine the robustness of the classification scheme for these aquifers.

As well as there being a requirement for additional transmissivity data, additional specific capacity and yield data would be required across much of Scotland to make the scaling up of this data viable. A similar study in Ireland (Wright 2000) noted that at least 20-50 pairs of yield and specific capacity values would be required to determine the productivity class of an aquifer. Table 4 shows that this criterion is not fulfilled at present for several stratigraphic groups across Scotland. 


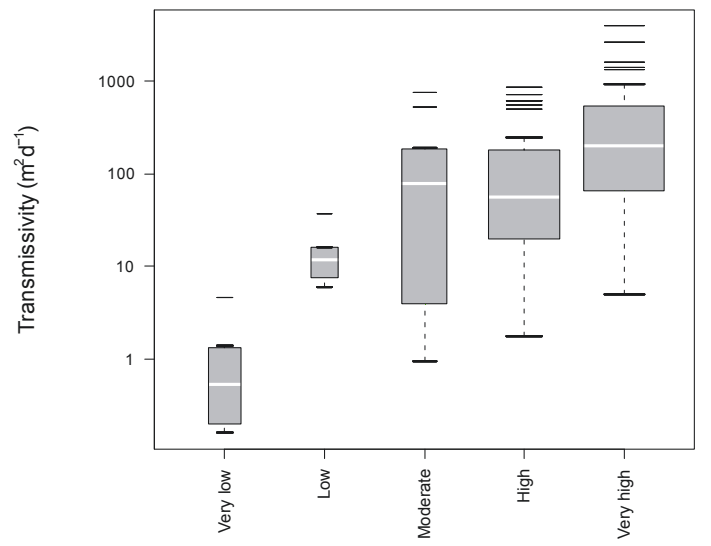

Aquifer productivity category

(a)

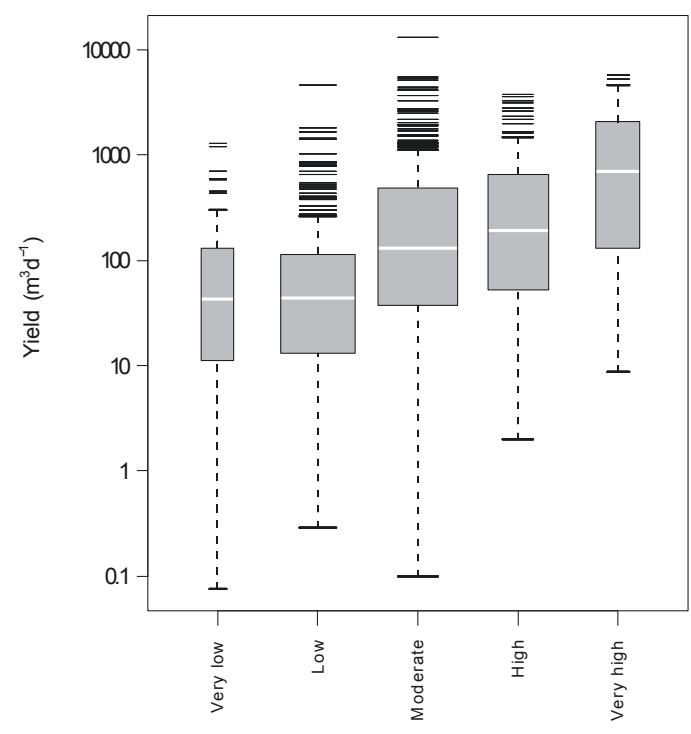

Aquifer productivity category

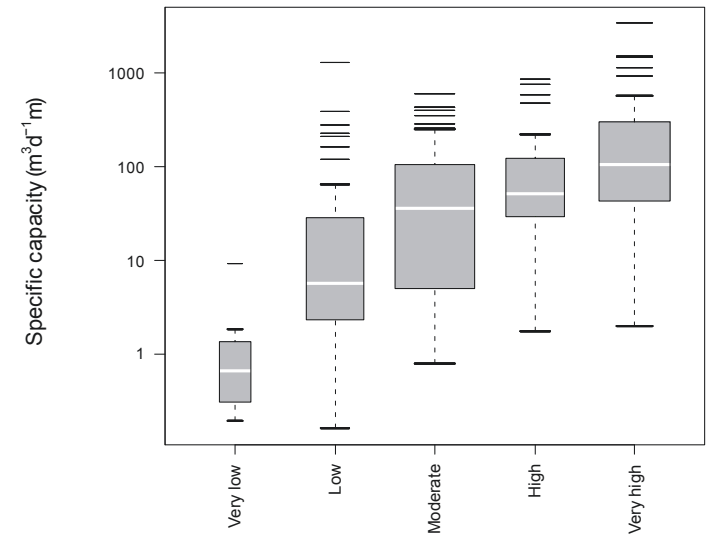

Aquifer productivity category

(b)

(c)

Figure 7. Boxplots of available (a) transmissivity, (b) specific capacity and (c) yield data for bedrock aquifers versus bedrock aquifer productivity (after MacDonald et al., 2004). 


\section{Conclusions}

Analysis of transmissivity, specific capacity and borehole yield data from the SAPD has confirmed that aquifers of Quaternary and Permo-Triassic age are the most productive in Scotland, followed by those of Carboniferous and Devonian age. The highest borehole yield values are seen in Carboniferous aquifers, but this is largely due to the presence of old mine workings, which artificially increase aquifer permeability.

Several factors are likely to affect adversely the reliability of borehole yield data across Scotland, although there remains a reasonably strong correlation between yield and both specific capacity and transmissivity data. There is a stronger correlation between specific capacity and transmissivity data. Given that few transmissivity values are available and that many have been derived from single borehole pumping tests, it may be a viable alternative to use specific capacity data to assess aquifer productivity in Scotland.

Transmissivity, specific capacity and borehole yield data from the SAPD confirm the validity of the recent bedrock aquifer productivity map of Scotland (MacDonald et al. 2004), with a strong correlation between the two. Despite possible bias, particularly in borehole yield data, similar trends are seen in all three datasets. The only slight discrepancy is in the transmissivity data for moderately and highly productive aquifers, whereby the latter category has a lower median transmissivity value. Further investigations are required to determine whether this discrepancy is still present with a larger dataset.

Comparison with the bedrock aquifer productivity classes shows that transmissivity data are scarce for aquifers of very low or low productivity and there are few borehole yield or specific capacity data available for very low productivity aquifers. This highlights the need for more reliable data, as these categories of aquifer are present across the majority of Scotland.

Acknowledgements. This paper is published by permission of the Executive Director of the British Geological Survey (NERC). The project was partly funded by the Scottish Environment Protection Agency and coordinated by the Scotland and Northern Ireland Forum for Environmental Research. 


\section{References}

ALLEN, D.J., BREWERTON, L.J., COLEBY, L.M., GIBBS, B.R., LEWIS, M.A., MACDONALD, A.M., WAGSTAFF, S.J. \& WILLIAMS, A.T. 1997. The physical properties of the major aquifers in England and Wales. British Geological Survey Technical Report, WD/97/34, British Geological Survey, Keyworth.

BANKS, D., MORLAND, G., FRENGSTAD, B. 2005. Use of non-parametric statistics as a tool for the hydraulic and hydrogeochemical characterization of hard rock aquifers. Scottish Journal of Geology, 41 (1), 69-79.

BETSON, M. \& ROBINS N. S. 2007. Using specific capacity to assign vulnerability to diffuse pollution in fractured aquifers in Scotland. In: KRÁSNÝ, J. \& SHARP, J. M. (eds) Groundwater in fractured rocks, IAH Selected Papers, 9. Taylor and Francis, London.

BRITISH GEOLOGICAL SURVEY. 1988. Hydrogeological Map of Scotland, 1: 625 000, British Geological Survey, Edinburgh.

CLEWS, J., FITZSIMMONS, V. \& SIMPSON, E. 2005. Groundwater challenges of the Water Framework Directive in Scotland (0-60 in 12 months). Scottish Journal of Geology, 41 (1), 13-20.

EUROPEAN COMMISSION. 2000. Directive 2000/60/EC of the European Parliament and of the Council of 23 October 2000 establishing a framework for Community action in the field of water policy. OJL 327, 22.12.2000, 1-73.

JONES, H.K., MORRIS, B.L., CHENEY, C.S., BREWERTON, L.J., MERRIN, P.D., LEWIS, M.A., MACDONALD, A.M., COLEBY, L.M., TALBOT, J.C., MCKENZIE, A.A., BIRD, M.J., CUNNINGHAM, J. \& ROBINSON, V.K. 2000. The physical properties of minor aquifers in England and Wales. British Geological Survey Technical Report, WD/00/04, British Geological Survey, Keyworth.

LOGAN, J. 1964. Estimating transmissibility from routine production tests of water wells. Ground Water, 2(1), 35-37.

MACDONALD, A.M., BALL, D.F. \& Ó DOCHARTAIGH, B.É. 2004. A GIS of aquifer productivity in Scotland: explanatory notes. British Geological Survey Commissioned Report, CR/04/047N, British Geological Survey, Keyworth.

MACDONALD, A.M., ROBINS, N.S., BALL, D.F. \& Ó DOCHARTAIGH, B.É. 2005. An overview of groundwater in Scotland. Scottish Journal of Geology, 41 (1), 3-11.

MISSTEAR, B.D.R. 2001. The value of simple equilibrium approximations for analysing pumping test data. Hydrogeology Journal, 9, 125-126.

Ó DOCHARTAIGH, B.É., BALL, D.F., BROWNE, M.A.E., SHAND, P., MACDONALD, A.M., ROBINS, N.S. \& MCNEILL, G.W. 1999. The Upper Devonian Sandstone Aquifer of 
Fife. British Geological Survey Technical Report, WD/99/39, British Geological Survey, Keyworth.

Ó DOCHARTAIGH, B.É. 2004. The physical properties of the Upper Devonian/Lower Carboniferous aquifer in Fife. British Geological Survey Internal Report, IR/04/003, British Geological Survey, Keyworth.

ROBINS, N.S. 1990. Hydrogeology of Scotland, HMSO, London.

ROBINS, N.S. \& BALL, D.F. (EDS.) 2006. The Dumfries Basin aquifer. British Geological Survey Research Report, RR/06/02, British Geological Survey, Keyworth.

ROBINS, N.S. \& BUCKLEY, D.K. 1988. Characteristics of the Permian and Triassic aquifers of south-west Scotland. Quarterly Journal of Engineering Geology, 21, 325-329.

SCOTTISH WATER, 2005. Public Water Supplies in Scotland 2003-2004. Annual Water Resources Survey.

SEPA, 2003. Groundwater Protection Policy for Scotland. Environmental Policy Number 19.

WOODS, S. C., YOUNGER, P. L. \& ROBINS, N. S. 1999. Long term changes in the quality of pollutant mine water discharges from abandoned underground coal workings in Scotland. Quarterly Journal of Engineering Geology, 32 (1), 69-79.

WRIGHT, G.R. 2000. QSC graphs: an aid to classification of data-poor aquifers in Ireland. Geological Society, London, Special Publications, 182, 169-177. 